\author{
石油技術協会誌 第 66 巻 第 1 号 (平成 13 年 1 月) \\ JOURNAL OF THE JAPANESE ASSOCIATION FOR PETROLEUM TECHNOLOGY \\ VOL. 66, NO. 1 (Jan., 2001)
}

$\overline{\text { 総 } \quad \text { 説 }}$

\title{
貯留岩分布予測における地質モデルの役割*
}

$$
\text { 荒戸 裕之** } \text { 高橋 明久*** }
$$

(Received August, 31, 2000; accepted November 17, 2000)

\section{Roles of geological models in distribution prediction for petroleum reservoirs}

\author{
Hiroyuki Arato and Akihisa Takahashi
}

\begin{abstract}
In the future petroleum exploration, it is presumed that technology for prediction of reservoir distribution become more important to reduce geological risks.

Improved prediction of reservoir distribution is attempted by combination of $3-\mathrm{D}$ seismic data and other exploration information. As the unique interpretation is not obtained from these data in most cases, it is necessary to make conceptual geological models intervene.

Each interpretation method utilizes different state and degree of intervention of conceptual models. In the case of seismic attribute analyses, for example, conceptual geological models may be adopted with comparison on the basis of visible similarity. In the case of sequence stratigraphic analyses, in contrast, sequence stratigraphic model must be constructed and adopted as much complex models as concepts for stratal genesis. Furthermore, stratigraphic and sedimentary geological simulation by computer is deductive method in combination with several conceptual models of different types such as facies models and sequence models.

Methods for prediction of reservoir distribution, based on the intervention of conceptual geological models, are applicable in the exploration of subtle traps such as stratigraphic traps which explorationists must face in the near future. Also such an approach must be significant in the extraction of new exploration play concepts within well-explored proven petroleum systems. In oil and gas fields of development and production stages with abundant petroleum geological information, heterogeneous distribution of reservoir properties and seal capacities can be discussed genetically based on the adoption of sedimentary geological conceptual models.
\end{abstract}

Key words : reservoir distribution, petroleum system, trap, stratigraphic trap, geologic model, facies model, attribute analysis, sequence stratigraphy

* 平成 12 年 5 月 24 日, 平成 12 年度石油技術協会春季講演会地 質・探鉱部門シンポジゥム「石油探鉱・開発に扔ける眝留 岩性状の分布予測技術」に扔いて講演 This paper was presented at the 2000 JAPT Geology and Exploration Symposium entitled "Technology for prediction of reservoir distribution and property in petroleum exploration and development" held in Niigata, Japan, May 24, 2000.

** 帝国石油(侏)探鉱部 Exploration Department, Teikoku Oil Co., Ltd.

***石油資源開発侏探鉱本部 Exploration Division, Japan Petroleum Exploration Co., Ltd.

Copyright (C) 2001, JAPT

\section{1.はじめに}

スピンドルトップで背斜構造頂部での試掘に成功した 1901年から約一世紀の間に，石油探鉱家は世界中のお㇒ な背斜構造に試掘井を掘削し, 数多くの構造トラップで 油・ガス田を発見してきた。その結果，今日では，難地 形地域や超大水深海域, あるいは政治的な紛争地域など 以外では大規模な未探鉱背斜構造の発見はなかなか期待 し難くなり, 必然的に, これまで優先度の低かった難卜 ラップ (subtle traps ; Hulbouty， 1982)をも今後の探 
鉱対象として注目せざるを得ない状況に至っている。難 トラップの探鉱では，地質リスクを軽減するために，こ れまで以上に貯留岩分布予測技術への依存度が高まるこ とが予想される。

本稿では，第一に，今後の石油・天然ガスの探鉱にお いて，貯留岩分布を精度良く予測する技術がいかに重要 であるかについて述べる。これに続いて，震探アトリ ビュート解析の技術を適用した貯留岩分布予測の例を紹 介し，概念的な地質モデルの必要性について述べる。第 三に，シーケンスモデルの概要を紹介し，あわせて眝留 岩分布予測におけるシーケンスモデルの位置づけについ て述べる。そして最後に，油・ガス田の開発・生産段階 での地質モデル適用の必要性について簡単に述べる。

\section{2. 貯留岩分布予測技術の必要性}

\section{1 石油探鉱とは?}

一般に，石油探鉱とは「石油や天然ガスが地中に濃集 して鉱床を形成しているところを見い出すこと」と定義 される(小松, 1983)。今日の石油鉱業界で一般的に受け 入れられている石油システムの概念 (図 1; Magoon and Dow, 1994）によれば, 石油や天然ガスの鉱床は, (1)熟成根源岩の分布，(2)炭化水素の排出・移動機構の成 立, ならびに(3)トラップの存在，の三条件を満たす場所
に成立する（図 2 )。しかし，これらの条件はいずれあ 未知の部分の多い自然現象で，かつ，直接目で見ること のできない地下での現象であるため，すべての条件を満 たす場所を特定し得るケースはまれであり，むしろ，予 測が的中する「成功確率」を高めるために技術力が注ぎ 込まれる。また, 鉱床の発見から開発・生産に至る一連 の作業は, 企業の営利活動として行われるので,「発見 効率」の高さが求められる。すなわち，石油探鉱は「可 能な限り高い精度で, 効率よく石油システムの評価を行 うこと」と言いかえることができる。

\section{2 トラップとは?}

実際に油・ガス田が発見されるためには，まず第一 に，その成立が予測される石油システム，あるいは成立 の確認された石油システム内に分布するトラップを対象 に試掘が実施される。

石油探鉱におけるトラップとは，「成因にかかわらず， 十分な量の石油・天然ガスを集積させることのできる岩 石の地下における幾何学的な配置」と定義される (North, 1985)。炭化水素が地下で濃集するための『器』 としてのトラップは，貯留岩の分布および上方・側方 シールの存在により成立する（Biddle and Wielchowsky，1994）。したがって，成立している石油システム の中において，良好な性状を有する眝留岩の分布，なら

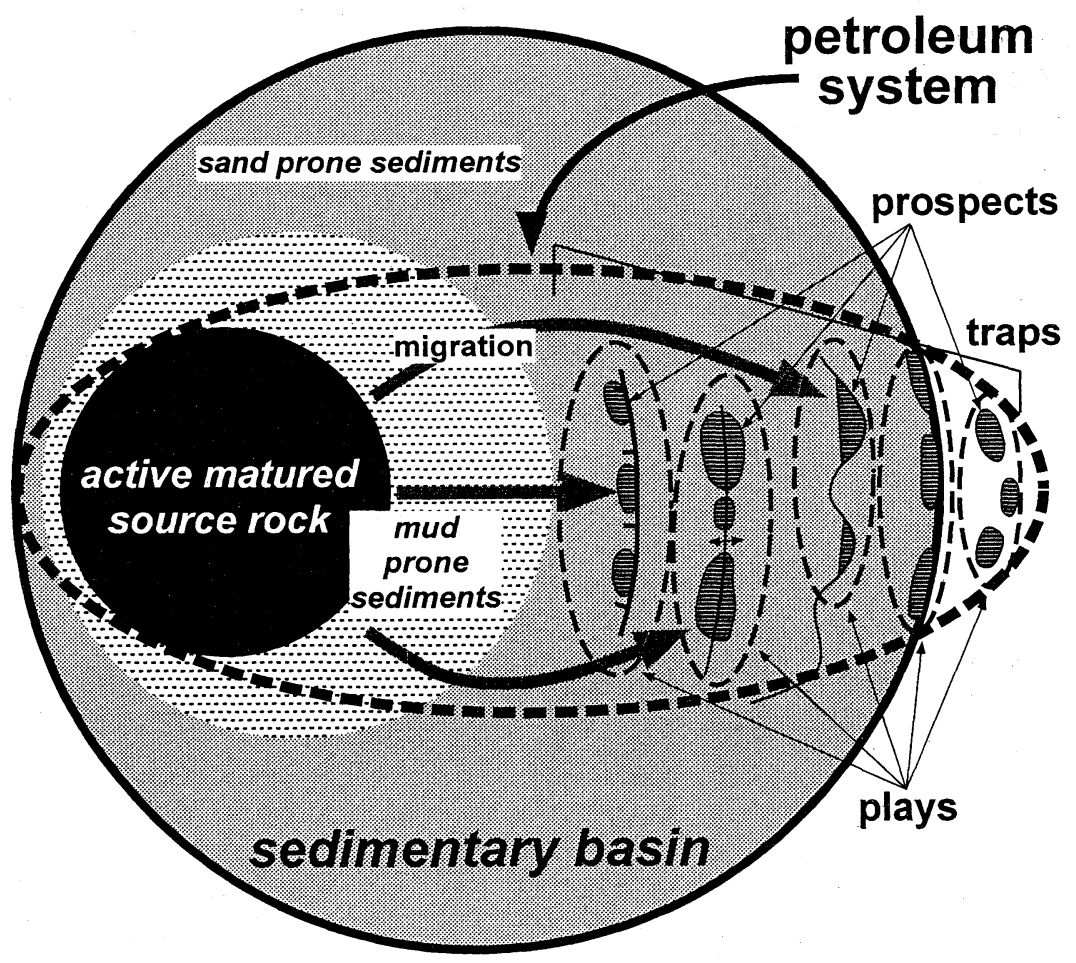

図 1 石油システムの範囲と構成要素。Magoon and Dow (1992) を改編 


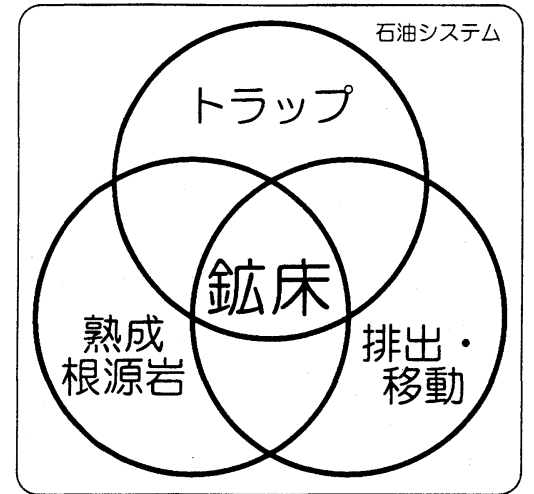

図 2 石油システムを構成する三要素と石油・天 然ガス鉱床成立の条件。 Magoon and Dow (1992) に基づく

びにその上方および側方におけるシール能力を有する帽 岩の分布を予測することが，石油探鉱の成功確率の向上 を導く。

トラップタイプにはさまざまな種類のあることが古く から報告されており，その分類が試みられている (Heroy, 1941 ; Wilhelm, 1945 など) が, 今日の石油鉱 業界では，(1)構造トラップ，(2)層位トラップ，(3)組み合 わせトラップ，の 3 区分が広く受け入れられている（三 土, 1963 ; 木下, 1973 ; North, 1985, Biddle and Wielchowsky, 1994 など)。さらに，構造トラップは背斜トラッ プや断層トラップなどに, 層位トラップは尖滅トラップ や不整合トラップなどに細分される(図 3 )。

\section{3 なぜ貯留岩分布に着目するか?}

これまでに世界中で発見された油・ガス田数とその確 認埋蔵量をトラップタイプ別に比較すると，構造トラッ プ，とくに背斜トラップでの発見が他のトラップタイプ に比較して圧倒的に多い。加藤（1984）は，背斜構造を 含む構造トラップの(1)発見し易さ，(2)集油（集ガス）の 効率の良さ，の 2 点をその原因として指摘している。

図 4 に，なぜ背斜トラップが「発見され易かった」の か，その理由を示す。本図で，上段 (G-1〜 G-4) は構 造, 断層, 尖滅抢よび不整合の 4 トラップタイプの地質 断面概念図である。背斜卜ラップ (G-1) では，貯留岩 の分布様式にかかわりなく, 炭化水素プールが背斜構造 頂部付近において比較的垂直方向にスタックしている。 このような産状は断層トラップ(G-2) でも類似してお り，下盤の断層沿いにプールが集中している。これらに 対し, 尖滅トラップ (G-3) や不整合トラップ (G-4)の 層位トラップでは，貯留岩が尖滅する位置を正確に把握 しなければ，プールの位置を特定することは難しい。言 いかえるならば，構造トラップは地層の形態的特徴に基
構造トラップ

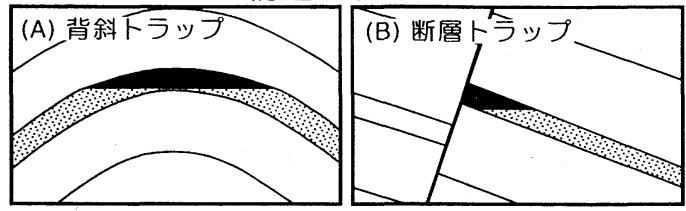

層位トラップ

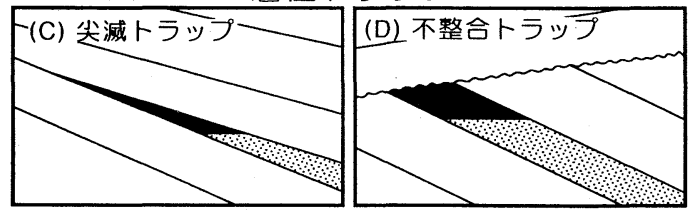

その他のトラップ

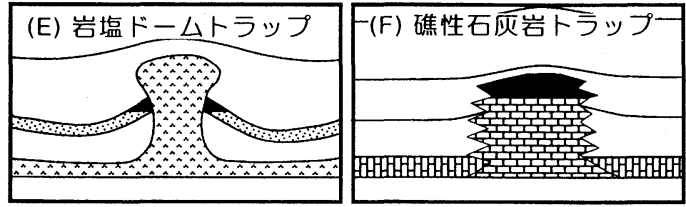

図 3 トラップの分類

づいて摘出され得るが, 層位トラップは地層の形態的特 徵だけからは摘出されにくい。

図 4 下段 (S-1〜S-4) は，上段の地質断面を震探断面 で観察した場合の概念図である。背斜トラップにおいて は，多少，貯留岩分布に関する情報が不足していたとし ても，探鉱初期段階の試掘井は Well Location 2 に掘削 されるであろう。むしろ, 貯留岩分布の知識が相当に蓄 積されなければ, Well Location 1 や Well Location 3 に試掘井が掘削される可能性は少ない。これは，断層卜 ラップ (S-2) についてあ同様である。そして, 効率よ く探鉱ステージの作業を終えることができる。一方，尖 滅トラップ (S-3) や不整合トラップ (S-4) では, 貯留 岩分布に関する知識が十分に蓄積されていないと，どの 位置が探鉱初期段階の試掘井掘削に適しているか特定し 難い。すなわち，構造トラップの探鉱では貯留岩分布の 知識不足が致命的な地質りスクになる可能性は少なかっ たが，層位トラップの探鉱では精度の高い貯留岩分布の 把握こそが地質りスク低減の最大の決め手となる。

トラップ効率の面から見れば，層位トラップは背斜卜 ラップに大きく劣るかもしれない。したがって，今後ど んなに技術が進歩し，貯留岩分布を精度良く予測できる ようになったとしてあ，これまでに背斜トラップで発見 された資源量と同規模の成果をそのまま層位トラップに 期待することはできないであろう。しかし, 成立してい る層位トラップは実在するのであり，かつ，世界に残さ れた探鉱余地の現状から判断して，今後は層位トラップ の探鉱を制した者こそが石油鉱業で生き残っていくこと 

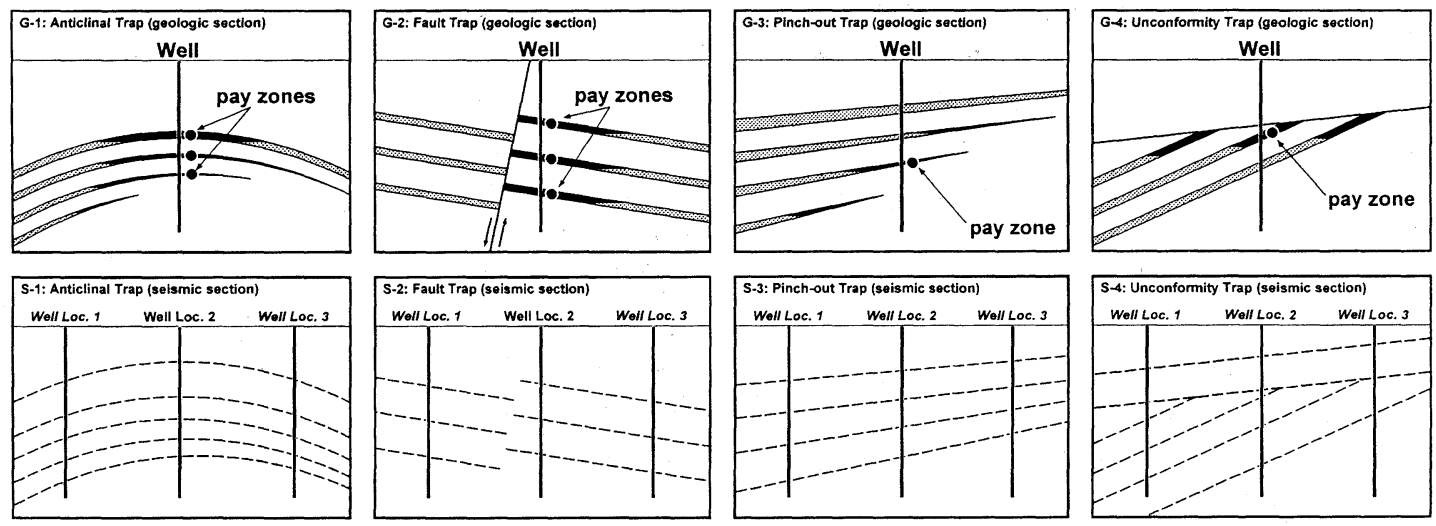

図 4 トラップタイプごとのプールの分布様式, ならびにその地層形態からの予測性

ができるとも予測される。

\section{3. アトリビュート解析と地質モデル}

\section{1 震探アトリビュート解析への期待}

地表から直接知ることができない地下構造の把握は, 石油探鉱創生期からの課題であり, 早い時期から重磁力 探査・屈折法地震探査といった物理探査の手法が採用さ れてきた。そして, 現在の石油探鉱における物理探査の 主流となっている反射法地震探查は, 1960年代の CDP 重合法 (Mayne, 1967) の実用化によって地下構造に関 する情報量を飛躍的に増加させた。

反射法地震探査のデータの解析結果は屈折法のような 解釈図面ではなく，反射波そのものを加工して表示する ことで, 客観性のある分解能の高い地下構造断面図を与 える。構造解釈の際に注目するのは主として反射波の走 時であるが，反射波走時は最も基本的な震探アトリ ビュート（反射法地震探査データから導かれる幾何学 的・波動力学的・統計的な地下の特性を表現する指標 ; Chen and Sidney, 1997) と言うことができる。

また, 構造探査と並行して, 地震探査記録から貯留岩 や孔隙内流体の物性を把握するための試みも進められて きた。例えば眝留岩物性把握のためのインバージョン技 術 (Lindseth, 1979 ; Cooke and Schneider, 1983 ; Oldenburg et al., 1983）や，孔隙内流体把握のための AVO 解析法 (Ostrander, 1984 ; 藤井, 1999) は, 地震探查 データから理論的に貯留層特性を把握しょうとするアプ ローチである。ここで得られる音響インピーダンスや AVOアトリビュートも, 重要な震探アトリビュートの ひとつである。これ以外に広く用いられているあのに は, Taner et al. (1979) による複素トレースの振幅・位 相表示などがある。Chen and Sidney (1997) には, 現 在用いられているさまざまな震探アトリビュートが分類
されてまとめられている。

1970年後半に始まった三次元地震探査は, 二次元測線 の間隔を密にすることによって, 地下構造を三次元ボ リュームとして把握する技術である。基本概念は二次元 地震探査と変わらないが, 二次元格子データが空間ボ リュームデータに置きかわるために, より精密な地下構 造を記載することができ，さまざまな角度からデータを 見ることができる（例えばタイムスライス断面図）。

初期には, 費用面から限られた開発フィールドにしか 適用できなかった三次元地震探査であるが，1980年代以 降のフィールド技術・コンピュータ技術の発展によって 比較的安価に実施できるようになり，現在では探鉱段階 からの三次元地震探査も広く行われている。

三次元地震探查を用いた震探アトリビュート解析は, 精度の高い貯留岩分布予測に貢献すると期待される有望 な技術のひとつである。ここでのひとつの鍵は，震探ア トリビュート值と坑井から得られる物性データとのマッ チングであるが, 地球統計学 (Geo-statistics) 的な取り 扱い (Issaks and Srivastava, 1989 ; Hirsche et al., 1998 ; 吉岡, 1999）がひとつの回答を与えると考えられ る。また，1990年代に入ってからさまざまな三次元ボ リュームの可視化技術が開発され，三次元震探アトリ ビュート解析に大きく貢献している。

ここでは, 震探アトリビュート解析における注意点や 解釈例を紹介しながら, 震探アトリビュート解析におけ る概念的な地質モデルの必要性について考察する。

\section{2 貯留岩分布予測における地質モデルの必要性}

トラップの評価に関連して, 震探アトリビュート解析 による予測が望まれる貯留岩のパラメータは, 岩相, 層 厚, 孔隙率, 水飽和率, 浸透率, 温度, 圧力などであ る。これに対して反射法地震探査の理論では, 走時は地 層の弾性波伝搬速度の関数であり, また, 振幅は地層の 
弾性波伝搬速度と密度の関数として与えられる。

すなわち, 眝留岩の物性值が弾性波伝搬速度や密度の 関数であるならば，震探アトリビュート解析によって貯 留岩物性の直接的な推定が可能となるであろう。しかし 一般的には，震探アトリビュート值は複数の貯留岩物性 值の関数として与えられるのであり, 通常は, アトリ ビュート值が一義的に特定の眝留岩物性值を与えること はない。

したがって, 震探アトリビュート解析結果に基づいて 貯留岩分布や眝留岩物性值を解釈するためには，特殊な 場合を除き，貯留岩の堆積現象を説明することのできる なんらかの地質モデル（堆積相モデル）を適用して, 堆 積地質学的な解釈を行わなければならない場合が多い。 近年, 震探アトリビュート解析ならびにその可視化結果 に堆積相モデルを適用して, 貯留岩の分布様式や層厚な どの眝留岩パラメータを推定した結果について報告され
るようになってきている (Johnson, 1998 ; Marotta et al., 1998 ; Kidd, 1999 ; Brown, 1999 ; 井上ほか, 2000)。

\section{3 アトリビュート解析による貯留岩分布予測}

ここでは，代表的な震探アトリビュート值を用いて ネット砂岩層厚を求める場合の, 地質モデル・物理モデ ルの関与について考える。

図 5 は, 単純化したデルタのモデルであり, 坑井位置 における震探データの時間層厚（アイソクロン）とネッ 卜砂岩層厚が線型関係で近似できる場合の例である。こ の場合には, 元のアトリビュートの分布とネット砂岩層 厚分布の形態はほぼ等しく, 後者の推定は比較的容易で ある。ただし，等時間層厚線図からはネット層厚ゼロの 限界を示すことはできず，それは想定される地質モデル から推定することになる。

図 6 には，振幅値 $(\mathrm{A})$ を用いてネット砂岩層厚 $(\mathrm{C})$ を 推定する場合の例を示した。振幅とネット層厚の関係は
(A) Seismic Isochron Map

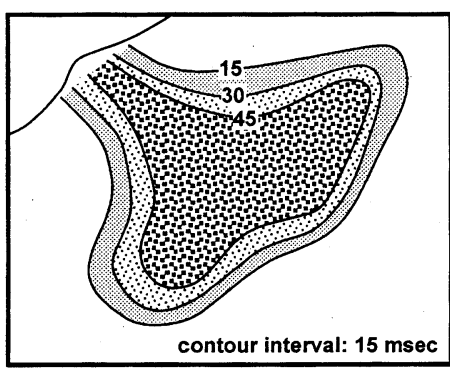

(B) Crossplot at Wells

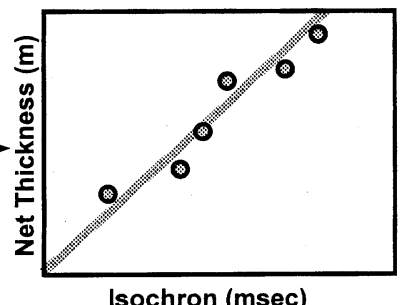

Isochron (msec) (c) Net Sand Map

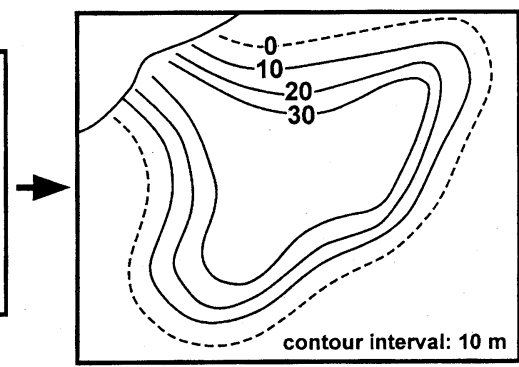

図 5 三次元地震探査データのアイソクロン図から有効層厚分布を予測する場合の概念図

(A) Seismic Amplitude Map

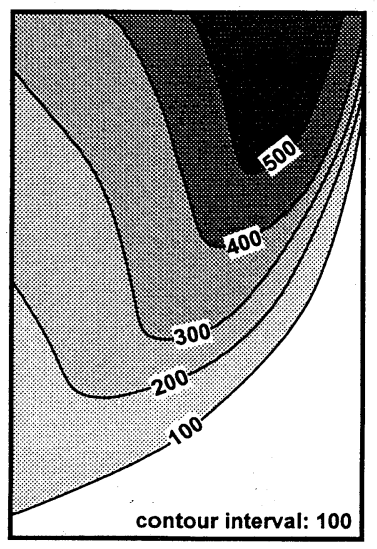

(B) Crossplot at Wells
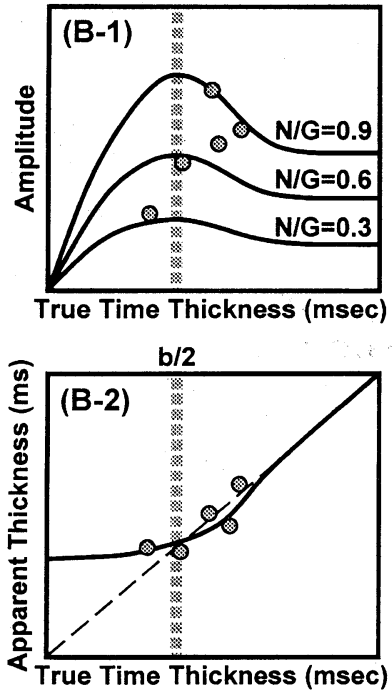

(C) Net Sand Map

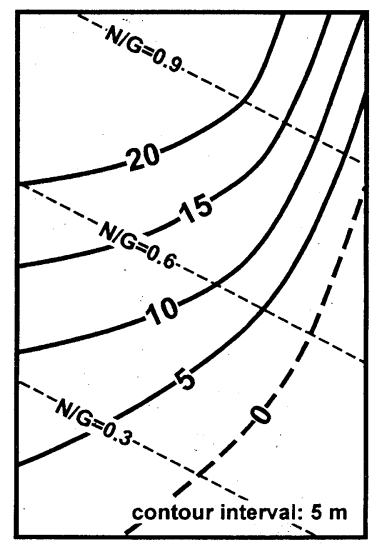

b/2: Tuning Thickness

図 6 三次元地震探查データの振幅図から有効層厚分布を予測する場合の概念図 
単純ではなく, クロスプロット（図6(B-1)）からあ分 かるように，ある振幅值を与えてもネット層厚は一意に は決まらない。振幅を扱う上では，チューニング効果と 言う物理モデルの理解 (Kallweit and Wood, 1982 ; 高 橋, 1999) が必要不可欠である。この物理モデルを認識 することにより，図6(A)の振幅分布において右上から 左下に伸びるノーズ状の張り出しが，チューニング効果 による見かけの張り出しであることが認識できる。ま た，この物理モデルを理解していないと図 6(B-1)のク ロスプロットを線型関係と誤認してしまう可能性もあ る。加えて，ネット層厚がある程度より大きくなると振 幅との相関がなくなるため，実際には振幅以外に見かけ 時間層厚（図 $6(\mathrm{~B}-2)$ ) あ参照するのが一般的である (Gastaldi et al., 1998)。また，振幅の変化はネットグロ ス比の变化にも依存するため, 単純な回州式を当てはめ ることは難しい。このケースでは，最初にネットグロス 比の分布を限られた坑井データから推定しているが, こ のような際にはその分布が想定している地質モデルと矛 盾がないかどうかを確認しながら作業を進める必要があ る。いずれにせよ，このような複雑なケースでは地質モ デル・物理モデルの知識を総動員して最終的な眝留岩物 性值の分布に至るのである。

\section{4 海底扇状地システムの例}

Kidd (1999) は，三次元地震探査記録の振幅情報を可 視化し，海底チャネルーレヴィーシステムとその沖側に 発達する海底扇状地システム，ならびにその周辺の堆積 相の平面的な広がりを捉えることに成功している（図 7 )。図 7 において，(a)が可視化ソフトウェア上で一定 の条件を与えて三次元地震探査記録から作成した振幅の 平面的な（あるいは空間的な）分布図，(b)がその堆積地 質学的な解釈結果である。

Kidd (1999) の例が示唆するとおり，(b)の堆積地質学 的な解釈が正しく行われるためには，海底チャネル〜海 底扇状地の堆積相モデルが解釈者の念頭になければなら ない。したがって，解釈者は貯留岩に関連するあらゆる 堆積システムとそこでの堆積相分布の特徴を概念モデル として熟知していなければならない。

また，堆積地質学的な概念モデルは，通常，平面的な いし空間的に表されているので，これと比較検討される べき震探アトリビュート情報も平面的，あるいは空間的 に可視化されなければならない。すなわち，震探アトリ ビュート情報に地質モデルを適用するためには，アトリ ビュート值を可視化するための作業やソフトウェアの介 在が不可欠である。

\section{5 河川チャネルの例}

震探アトリビュート值を可視化するまであなく，通常
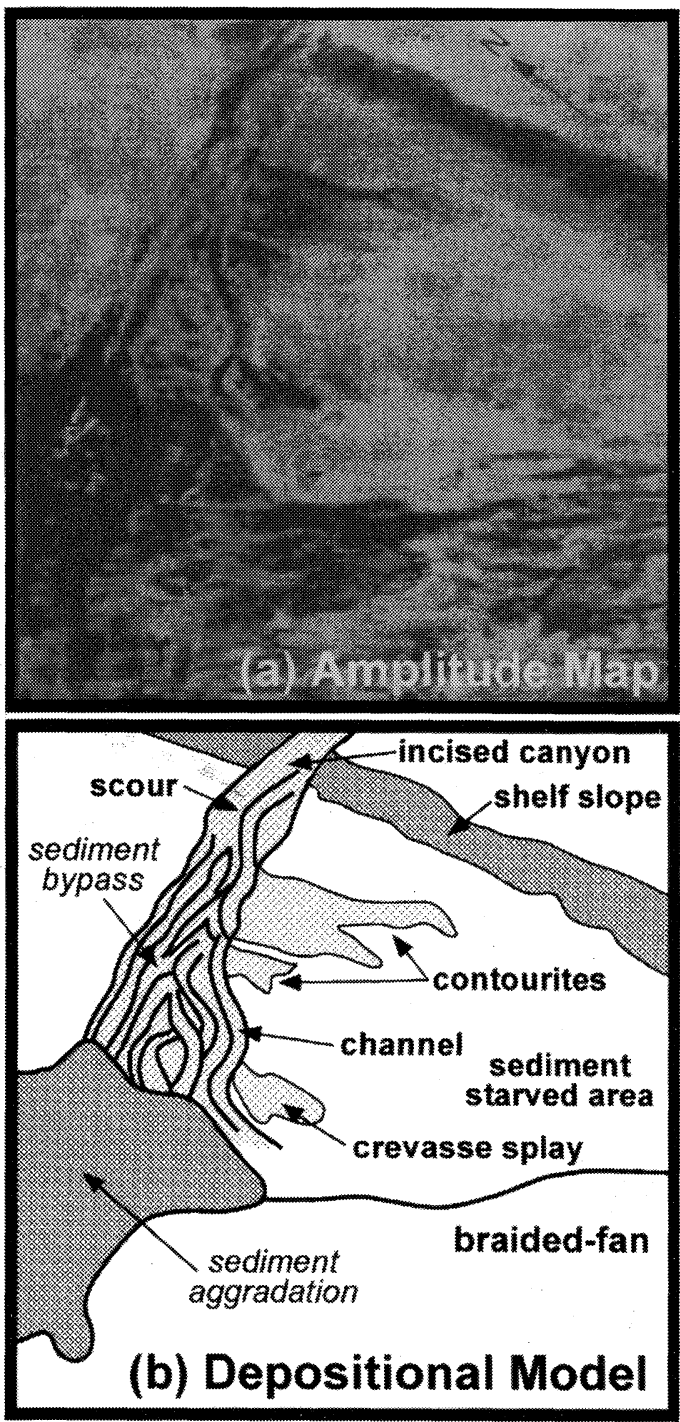

図 7 三次元地震探査振幅図 (Veritas DGC によ る）の地質モデルによる堆積システムの解釈 例。Kidd（1999）の Fig.9 (p. 705) を改編

の震探断面やタイムスライスがすでに堆積相分布をよく 反映している例もある。Brown (1999) は, 三次元地震 探査記録の時間断面と夕イムスライス上に視覚的に捉え ることのできる河川チャネルの例を示している(図 8 )。 (A)のタイムスライスでは, 蛇行するチャネルの形態が 一目瞭然である。（B）の時間断面では，その蛇行河川 チャネルが強振幅の途切れた反射波列として認められ る。

この例は, 適切な地質モデルが念頭にあれば, 可視化 した震探データの堆積地質学的な解釈は比較的容易であ ることを示す一方, それは平面的, 空間的分布が適切に 


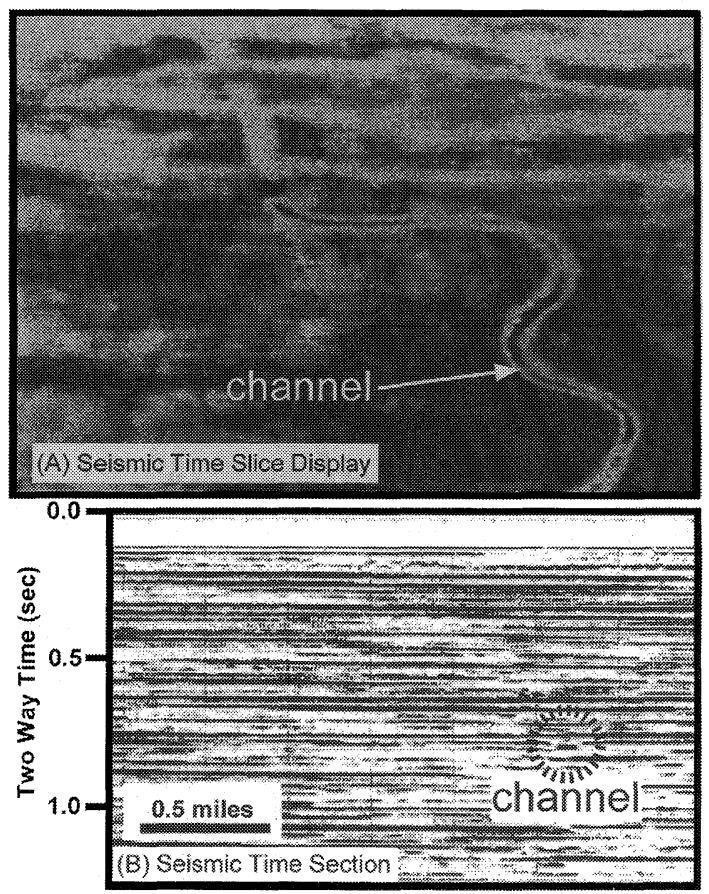

図 8 三次元地震探査記録断面およびタイムスライ ス表示に認められる河川チャネルの例。 Brown (1999) の Fig. 4-21 および Fig. 4-22 (p. 117) に加筆

可視化され得た場合のことであって，二次元の震探断面 上での堆積相モデルの適用の難しさを印象づけている。

\section{4. シーケンスモデル}

\section{1 シーケンス層序学の成立}

「反復性の, 成因的に関連を有する堆積物を, 時間層 序学的枠組みの中で研究する学問分野」を, シーケンス 層序学と呼ぶ (Vail, 1987)。

シーケンス層序学は，1970～1980年代の地震探査技術 の発展と震探記録の分解能向上を背景に震探層序学 （seismic stratigraphy）の手法として芽生えた。1980年 代後半以降, 堆積相モデルと相対海水準 (Posamentier et al., 1988) 変動の概念を組み込んで堆積地質学的な体 系を整えることによって, 地表地質や坑井地質データを あ含めた総合的な層序学的枠組みを提供するに至り,こ の十年間に急速な進歩と普及を遂げた。

\section{2 震探シーケンス解析}

シーケンス層序学は,「相対海水準サイクルに対応し て堆積サイクルが形成される」と言う地層の成因論に基 づいて, 堆積モデルやグローバルサイクルなどの論理的 枠組みを提供し，i）堆積相分布の予測性，ならびに ii）
層序学的解析精度の向上をあたらす（荒戸・高野, 1995)。

地震探鉱データのシーケンス解析は, 堆積サイクルの 概念やサイクルの階層性の概念を念頭に置いて行われる (図 9 )。その具体的内容は, 反射波列累重様式 (Mitchum, Jr. et al., 1977a) の認定, オンラップ, ダゥン ラップ, トップラップなどの反射波列端 (Mitchum, Jr. et al., $1977 \mathrm{a}$; 日本語表記は荒戸, 1993 ; 荒戸ほか, 1994 ; 荒戸, 1996, 1998 による) の摘出, ならびに反射波列端の 配列が示すシーケンス境界面 (Vail et al., 1984 ; Van Wagoner et al., 1987), 最大海成氾濫面 (Vail et al., 1984 ; Loutit et al., 1988) などの不連続面 (Mitchum et al., 1977a）の認定である。

震探シーケンス解析の手法は, 範囲の狭い三次元地震 探査記録にも適用可能であるが，むしろ広域的な長测線 の上で解釈が行われることを前提としている。これは, 震探アトリビュート解析の技術が, 三次元地震探査記録 を対象とすることで威力を発揮することと対照的であ る。

\section{3 シーケンスモデルの構築}

震探シーケンス解析の結果は, 反射波列（音響イン ピーダンスの境界面）が地層面と一致する同時間面を示 す（Vail et al., 1977）ことに基づいて, 地質断面に置き かえることができる。地震探査記録ばかりでなく，坑井 地質データや坑井物理検層データ, コアや地表地質デー 夕を対象としたシーケンス解析の手法 (Van Wagoner et al., 1987 その他) あ確立されており，それらすべてを 総合したものをシーケンス層序学的枠組みと呼んでい る。

適切に構築されたシーケンス層序学的枠組みからは, 対象とする地域における堆積シーケンス (Mitchum et al., 1977 b) のオーダーや階層構造, 堆積シーケンスを 構成する堆積体 (Brown and Fisher, 1977) の種類, 堆 積体を構成する堆積システム (Fisher and McGowen, 1967）の種類，さらにはそれらの空間的な広がりを読み 取ることができる。ある地域における典型的な堆積シー ケンスについて, シーケンス層序学的枠組みを整理した あのがシーケンスモデル（あるいはシーケンス層序堆積 モデル)である（図 9 )。

シーケンスモデルは, 具体的な数值を与えてシーケン スの形成過程を追跡する「数值モデル」と，地層尖滅様 式や地層累重様式および堆積過程を組み合わせてシーケ ンスの形成過程を概念的に構築する「概念モデル」に大 別される（荒戸，1998）。概念的なシーケンスモデルとし ては, 安定縁辺盆地の第3オーダー堆積シーケンスを対 象とした「エクソンモデル」（Vail, 1987 ; Posamen- 


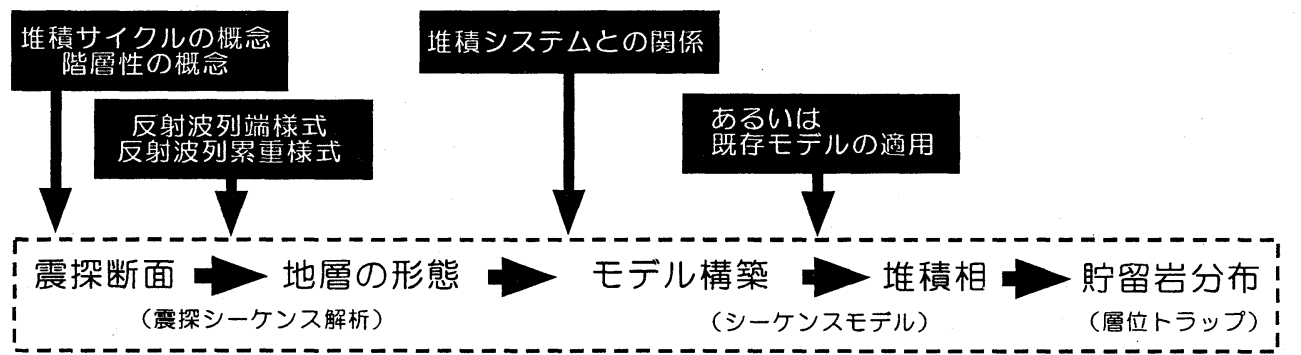

図 9 シーケンスモデル構築とその適用による貯留岩分布予測の流れ

tier et al., 1988) やランプマージンの第 3 オーダー堆積 シーケンスを対象とした「T-R サイクルモデル」 (Embry, 1988) などが知られている。近年では，日本の 前弧盆地における高次堆積シーケンスを対象としたモデ ル (Ito, 1995), 背弧盆地の第4オーダー堆積シーケンス を対象としたモデル (荒戸・保柳, 1995 ; Arato, 1999), リフト盆地の堆積シーケンスを対象としたモデル (Nummedal, 1994 ; Howell et al., 1994 など) の研究む 盛んになっている（荒戸・高野, 1995）。

\section{4 シーケンスモデルによる堆積相分布予測}

現実性の高いシーケンスモデルが構築されることに よって, 堆積システム, 堆積相の時間的, 空間的な配置 を議論することが可能となり，貯留岩分布を予測するこ とが可能となる（荒戸, 1998）。

図10は，エクソンモデル（安定縁辺盆地の第 3 オー ダー堆積シーケンス）における地層尖滅様式, 地層累重 様式，不連続面の関係(A)と，その堆積シーケンスにお いて想定され得る砂岩眝留岩の分布様式(B)を示してい る。安定縁辺盆地の大陸棚域において，広域的な地震探 查記録上に図10 (A)のような地層尖滅様式, 地層累重様 式に特徴づけられる堆積シーケンスが発見された場合, シーケンスモデルとして「エクソンモデル」を適用でき る可能性が高い。そして，この堆積シーケンスには図10 (B)のような砂岩貯留岩の分布が期待される。

シーケンス層序学の応用による眝留岩分布予測の手法 は，地震探查記録断面上で地層の形態的特徴の把握に基 づくと言う意味では，地層の形態的特徴に基づいて摘出 されてきた構造トラップの探鉱に類似している。しか し，この場合，眝留岩分布の把握ならびに層位トラップ の摘出は堆積相モデルの介在なくしては成し得ないと言 うところが，構造トラップの探鉱と大きく異なる。

\section{5 貯留岩分布予測におけるシーケンスモデルの応 用例}

今日では，シーケンス層序学を応用した貯留岩分布の 予測および解釈は，広く世界各地で実施されるように なった。

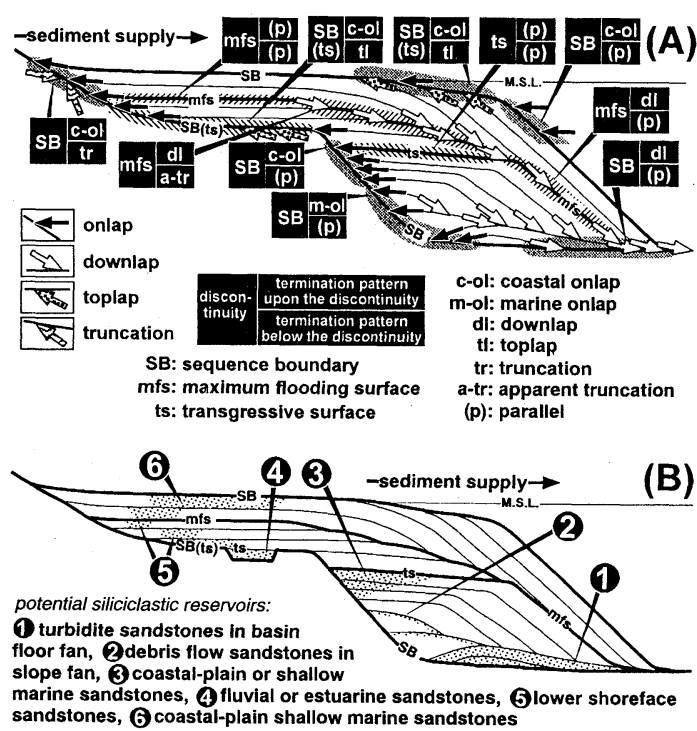

図10 安定縁辺盆地のシーケンスモデル (エクソン モデル）における地層尖滅様式，地層累重様 式と不連続面，堆積体の関係（A)，ならび にこのモデルから予測される砂岩眝留岩の分 布様式 (B)。荒戸・高野 (1995) を改編

近年，とくに大水深海域の石油・天然ガス探鉱におけ る有用性が主張されている（例えば Stow and Mayall, 2000)。大水深海域には大規模なタービダイト砂岩が発 達する場合があり，石油システムのあり方次第では巨大 油・ガス田を成立させている。シーケンスモデルからみ たそれらの眝留岩は, 盆地底扇状地を構成する砂岩ない し斜面に形成されたフィーダーチャネルを埋積する砂岩 である場合が多い。西アフリカ沖，ブラジル沖，メキシ コ湾，地中海，西オーストラリア沖，北海など，世界各 地で注目される大水深海域の堆積盆地では，このような 砂岩の平面的，層位的な分布を推定するために，シーケ ンス解析およびその結果構築されたシーケンスモデルが 応用されている (Guardado et al., 1990 ; Bruhn et al., 1998 ; Marotta et al., 1998 ; Aal et al., 2000 など)。こう 
した傾向は, 現在の陸域地下に分布する深海底堆積物に ついても同様である (Williams et al., 1998)。

シーケンスモデルによる砂岩貯留岩や炭酸塩貯留岩の 分布予測は, 大水深海域以外でも進められている。例え ば陸棚域では, 震探記録の分解能に比較して堆積物が薄 い場合が多く，モデルによる直接的な貯留岩分布予測は 困難な場合あある。このような場合は, 広域のシーケン ス層序学的な枠組みに基づき, 堆積物がシーケンスサイ クルにおけるどの堆積体に含まれるか, あるいは堆積体 を構成するどのような堆積システムに属するのかを絞り 込むことによって, 眝留岩分布の解釈および予測が行わ れる(例えば Spry and Ward, 1996)。

\section{5. 油・ガス田開発における地質モデルの寄与}

利用可能な石油地質データが比較的少ない探鉱初期段 階の地域における眝留岩分布は，おそらく非常に大まか にしか推定することはできないであろう。一方開発・生 産段階の油・ガス田では, 石油地質学的な情報密度が増 すととむに, 地層流体の挙動についての情報も加わり, 分布だけでなく貯留岩性状についての理解も飛躍的に高 まる。これに伴って, 多くの場合, 分布の確認されてい る貯留岩にも不均質性のあることが判明する。貯留岩の 不均質性, すなわち油・ガス田内における眝留岩性状の 空間的分布の予測は, より詳細な概念的堆積相モデルを 適用することにより議論することができる。

すなわち，概念的な地質モデルを主軸に据えた石油地 質学的検討は, 対象とする情報の精度や種類に応じて, 探鉱段階における貯留岩分布の把握に役立つだけでな く, 開発・生産段階の貯留層管理にも適用し得る技術で ある。

\section{6. まとめ}

今後の石油・天然ガス探鉱は, 層位トラップにその中 心を移していくと予想される。そして，層位トラップの 探鉱では, 精度の高い貯留岩分布予測技術への依存度が 高まるであろう。

精度の高い貯留岩分布予測は, 三次元地震探查記録を 中心とするさまざまの探鉱デー夕を組み合わせることに よって試みられているが, 多くの場合, それらのデー夕 から直接かつ一義的に解を得ることはできないため, そ の解釈には地質モデル, あるいは堆積地質学的モデルと 呼ばれるような概念モデルの介在が欠かせない。

眝留岩分布解釈における概念モデル介在の仕方, ある いはその度合いは, 解釈手法によって異なる。例えば, 地震探查記録のアトリビュート解析による貯留岩分布解 釈の場合, 地質モデルの適用方法は比較的単純である。
一方, 地震探查記録のシーケンス解析による貯留岩分布 解釈の場合, より複雑な概念モデルであるシーケンスモ デルを構築した上でこれを適用する必要がある。

地質学的, 堆積地質学的な概念モデルの介在による眝 留岩分布予測技術は, 今後の石油・天然ガス探鉱が直面 するであろう難トラップの探鉱において，地質リスク軽 減のために寄与すると考えられる。また，すでに探鉱密 度が熟成に達した石油システムにおいても，新たな探鉱 プレイを摘出するために役立つであろう。さらに, 石油 地質学的な情報密度の大きい開発段階での油・ガス田で は, 地質学的, 堆積地質学的な概念モデルを適用するこ とによって, 貯留岩性状の不均質性やその空間的分布を より詳細かつ成因論的に議論することが可能となろう。

以上のような，地質モデルを介した貯留岩分布予測の 技術は，探鉱段階における新たな探鉱プレイや具体的な プロスペクトの摘出につながるだけでなく，開発段階で の眝留岩性状の不均質性の把握を経て, 正確な可採埋蔵 量の算定や効率的な開発計画の策定に寄与すると考えら れる。

\section{謝 辞}

The American Association of Petroleum Geologists および The Society of Exploration Geophysicists には それぞれ著作権を有する図の転載を許可していただい た。これらの機関に対し, 感謝と尊敬の意を表したい。

\section{引 用 文 献}

Aal, A. A., Barkooky, E., Gerrits, M., Meyer, H., Schwander, M. and Zaki, H., 2000 : Tectonic evolution of the Eastern Mediterranean Basin and its significance for hydrocarbon prospectivity in the ultradeepwater of the Nile Delta. The Leading Edge, 19, 1086-1102.

荒戸裕之, 1993 ：シーケンス層序学と石油の探鉱 (その 1 : 概観). 石油の開発と備蓄, 26, 97-114.

荒戸裕之, 1996 : 反射波列端. 地学団体研究会編, 新版 地学事典, 平凡社, 東京, 1055 .

荒戸裕之, 1998 ：シーケンス層序堆積モデル. 堆積学研 究会編, 堆積学辞典, 朝倉書店, 東京, 168 ,

Arato, H., 1999 : A Facies Model for a Quaternary Hierarchical Depositional Sequences in the Niigata Basin, Central Japan : An Approach to Prediction of Petroleum Reservoir Distribution in Back-arc Basins. Jour. Jap. Petrol. Inst., 42, 1-11.

荒戸裕之・保柳康一, 1995 ：新潟堆積盆地における 3 夕 イプの第 4 オーダー堆積シーケンスモデル. 地質学論 集, no. 45, 118-139.

荒戸裕之・亀尾浩司・保柳康一, 1994 ：背弧堆積盆地に おけるシーケンス解析一新潟県蒲原地域の例一。石技 
誌, 59, 18-29

荒戸裕之・高野 修, 1995 : 石油・天然ガスの探鉱にお けるシーケンス層序学の意義. 地質学論集, no. $45,43-$ 60 .

Biddle, K. T. and Wielchowsky, C. C., 1994 : Hydrocarbon Traps, In Magoon, L. B. and Dow, W. G., eds., The. Petroleum System-from Source to Trap, Mem. Amer. Assoc. Petrol. Geol., no. 60, 219-235.

Brown, A. R., 1991 : Interpretation of Three-Dimensional Seismic Data, Fifth Edition. Mem. Amer. Assoc. Petrol. Geol., no. 42, 514 p.

Brown, Jr., L. F. and Fisher, W. L., 1977 : Seismicstratigraphic interpretation of depositional systems : Examples from Brazillian rift and pull-apart basins. In Payton, C. E., ed., Seismic stratigraphyapplications to hydrocarbon exploration. Mem. Amer. Assoc. Petrol. Geol., no. 26, 213-348.

Bruhn, C. H. L., Arienti, L. M., Castro, D. D., Adams, T., Barros, A.P., Sarzenski, D. J. and Camoleze, Z., 1998 : High-Resolution Sequence Stratigraphy and Reservoir Characterization of Oligocene/Miocene Sand-Rich Turbidites from Deep-Water Campos Basin, Brazil. Extended Abstracts Volume, 1998 AAPG International Conference \& Exhibition, November 8-11, 1998, Rio de Janeiro, Brazil, 772-773.

Chen, Q. and Sidney, S., 1997 : Seismic attribute technology for reservoir forecasting and monitoring. The Leading Edge, 16, 445-456.

Cooke, D. A. and Schneider, W. A., 1983 : Generalized linear inversion of reflection seismic data. Geophysics, 48, 665-676.

Embry, A. F., 1988, Triassic sea-level changes : evidence from the Canadian Arctic Archipelago. In Wilgus, C. K., Hastings, B. S., Kendall, C. G. St. C., Posamentier, H. W., Ross, C. A. and Van Wagoner, J. C., eds., Sea-level changes : An integrated approach. Spec. Publ. Soc. Econ. Paleont. Miner., no. 42, 249259.

Fisher, W. L. and McGowen, J. H., 1967 : Depositional systems in the Wilcox Group of Texas and their relationship to occurrence of oil and gas. Trans. Gulf Coast Assoc. Geol. Soc., 17, 105-125.

藤井康友, 1999 : AVO 解析技術. 物理探査ハンドブッ ク第 2 巻反射法地震探査, 物理探査学会, 86-90.

Gastaldi, C., Roy, D., Doyen, P. and Boer, L. D., 1998 : Using Bayesian simulations to predict reservoir thickness under tuning conditions. The Leading Edge, 17, 539-543.

Guardado, L. R., Gamboa, L. A. P. and Lucchesi, C. F., 1990 : Petroleum Geology of the Campos Basin, Brazil, a Model for a Producing Atlantic Type Basin. In Edwards and P. A. Santogrossi, eds., Divergent/passive margin basins. Mem. Amer. Assoc. Petrol. Geol., no. 48, 3-79.
Heroy, W. B., 1941 : Petroleum geology, In 1888-1938 : Geological Society of America 50th Anniversary Volume, 535-536.

Hirsche, K., Boerner, S., Kalkomey, C. and Gastaldi, C., 1998 : Avoiding pitfalls in geostatistical reservoir characterization: A survival guide. The Leading Edge, 17, 493-504.

Howell, J. A., Flint, S. S. and Keating, J. M., 1994 : Sequence stratigrpahic reappraisal of the Upper Jurassic reservoirs of the south Central Graben, UK North Sea. Abstract of AAPG Hedberg Research Conference "Application of Sequence Stratigraphy to Oil Field Development," September 5-8, 1994, Paris, France, 85-89.

Hulbouty, M. T., 1982 : The Time Is Now for All Explorationists to Purposefully Search for the Subtle Trap, In M. T. Halbouty, ed., The Deliberate Search for the Subtle Trap. Mem. Amer. Assoc. Petrol. Geol., no. 32, 1-10.

井上正澄 - 坂牧和博 - 町田幸弘 - 佐伯龍男 - 岡崎隆臣, 2000 : ガボン沖合既存油田間鞍部における新油層の発 見一voxel 技法による眝留層分布予測一。石技誌, 65, 557-570.

Issaks, E. R. and Srivastava, R. M., 1989 : Applied geostatistics. Oxford University Press. New York, 561 p.

Ito, M,1995: Volcanic ash layers facilitate highresolution sequence stratigraphy at convergent plate margins : an example from the PlioPleistocene forearc basin fill in the Boso Peninsula, Japan. Sedim. Geol., 95, 187-206.

Johnson, M. G., 1998 : New Geoscience Technologies : The Key to Profitably Finding and Developing Hydrocarbon Resources. Extended Abstracts Volume, 1998 AAPG International Conference \& Exhibition, November 8-11 1998, Rio de Janeiro, Brazil, 266-268

Kallweit, R. S. and Wood, L. C., 1982 : The limits of resolution of zero-phase wavelets. Geophysics, 47, 1035-1046.

加藤正和, 1984 : 埋蔵量および資源量. (社)石油学会編, ガ イドブック世界の大油田, 技報堂出版, 東京, 505-519.

Kidd, G. D., 1999 : Fundamentals of 3-D seismic volume visualization. The Leading Edge, 18, 702712 .

木下浩二, 1973 : 石油資源の科学. 共立出版, 東京, 173 p. 小松直幹, 1983 : 探鉱手順概論. 石油技術協会編, 石油鉱 業便覧, 55-56.

Lindseth, R. O., 1979 : Synthetic sonic logs-a process for stratigraphic interpretation. Geophysics, 44, 326.

Loutit, T. S., Hardenbol, J., Vail, P. R. and Baum, G. R., 1988 : Condensed sections : the key to age determination and correlation of continental margin se- 
quences. In Wilgus, C. K., Hastings, B. S., Kendall, C. G. St. C., Posamentier, H. W., Ross, C. A. and Van Wagoner, J. C., eds., Sea-level changes: An integrated approach. Spec. Publ. Soc. Econ. Paleont. Miner., no. 42,183-213.

Magoon, L. B. and Dow, W. G., 1994 : The Petroleum System. In Magoon, L. B. and Dow, W. G., eds., The Petroleum System-from Source to Trap. Mem. Amer. Assoc. Petrol. Geol., no. 60, 3-24.

Marotta, D., Alexander, C. S., Coterill, K., Hartman, K., Pasley, M., Stielar, T. C., Tari, G., Binga, L. and Lehner, B., 1998 : The Use of 3D Visualization for Understanding Tertiary Deep-water Clastic Systems : a West Africa Example. Extended Abstracts Volume, 1998 AAPG International Conference \& Exhibition, November 8-11 1998, Rio de Janeiro, Brazil, 746-747.

Mayne, W. H., 1967 : Practical considerations in the use of common reflection point techniques, Geophysics, 32, 225-229.

Mitchum, Jr., R. M., Vail, P. R. and Sangree, J. B., 1977 a : Seismic stratigraphy and global changes of sea level, Part 6 : Stratigrpahic interpretation of seismic reflection patterns in depositional sequences. In Payton, C. E., ed., Seismic stratigraphy-applications to hydrocarbon exploration. Mem. Amer. Assoc. Petrol. Geol., no. 26, 117-133.

Mitchum, Jr., R. M., Vail, P. R. and Thompson, III, S., 1977b : Seismic stratigrpahy and global changes of sea level, Part 2: The depositional sequence as a basic unit for stratigrpahic analysis, In Payton, C. E., ed., Seismic stratigraphy-applications to hydrocarbon exploration. Mem. Amer. Assoc. Petrol. Geol., no. 26, 53-62.

三土智芳, 1963 : 鉱床概説. 石油技術協会編, 石油鉱業便 覧, 1-20.

North, F. K., 1985 : Petroleum geology. Allen and Unwin, Boston, $553 \mathrm{p}$.

Nummedal, D., 1994 : Seismic stratigraphy of rift basin lakes in the Bohai basin, China. Abstract of AAPG Hedberg Research Conference "Application of Sequence Stratigraphy to Oil Field Development," September 5-8, 1994, Paris, France, 144-147.

Oldenburg, D. W., Scheuer, T. and Levy, S., 1983 : Recovery of the acoustic impedance from reflection seismograms. Geophysics, 48, 1318-1337.

Ostrander, W. J., 1984 : Plane-wave reflection coefficients for gas sands at nonnormal angles-ofincidence. Geophysics, 49, 1637-1648.

Posamentier, H. W., Jervey, M.T. and Vail, P. R., 1988 : Eustatic controls on clastic deposition I-
Conceptual framework. In C. K. Wilgus, B. S. Hastings, C. G. St. C. Kendall, H. W. Posamentier, C. A. Ross and J.C. Van Wagoner, eds., Sea-level changes: Anintegrated approach, Spec. Publ. Soc. Econ. Paleont. Miner., no. 42, 107-124.

Spry, T. B. and Ward, I., 1996 : The Gwydion discovery : a new play fairway in the Browse Basin. The APPEA Journal, 37, 87-104.

Stow, D. A. V. and Mayall, M., 2000 : Deep-water sedimentary systems : New models for the 21st century. Marine and Petroleum Geology, 17, 125-135.

高橋明久, 1999 : 垂直分解能. 物理探査ハンドブック第 2 巻反射法地震探査, 物理探査学会, 20-22.

Taner, W. T., Koehler, F. and Sheriff, A. R., 1979 : Complex seismic trace analysis. Geophysics, 44, 1041-1063.

Vail, P. R., 1987 : Seismic stratigraphy interpretation procedure. In Bally, A. W., ed., Atlas of seismic stratigraphy Part 1. Studies in Geol. Amer. Assoc. Petrol. Geol., 27, 1-9.

Vail, P. R., Todd, R. G. and Sangree, J. B., 1977 : Seismic stratigraphy and global changes of sea level, Part $5:$ Chronostratigraphic significance of seismic reflections. In Payton, C. E., ed., Seismic stratigraphy-applications to hydrocarbon exploration. Mem. Amer. Assoc. Petrol. Geol., no. 26, 99-116.

Vail, P. R., Hardenbol, J., and Todd, R. G., 1984 : Jurassic unconformities, chronostratigraphy, and sea-level changes from seismic stratigraphy and biostratigraphy. In Schlee, J. S., ed., Interregional unconformities and hydrocarbon accumulation. Mem. Amer. Assoc. Petrol. Geol., no. 36, 129-144.

Van Wagoner, J. C., Mitchum, Jr., R. M., Posamentier, H. W. and Vail, P. R., 1987 : Seismic stratigraphy interpretation using sequence stratigraphy, Part $2:$ Key definitions of sequence stratigraphy. In Bally, A. W., ed., Atlas of seismic stratigraphy. Studies in Geol. Amer. Assoc. Petrol. Geol., no. 27, 1115.

Wilhelm, O. G., 1945 : Classification of petroleum reservoirs. Bull. Amer. Assoc. Petrol. Geol., 29, 15371579 .

Williams, T. A., Graham, S. A. and Constenius, K. N., 1998: Recongnition of a Santonian Submarine Canyon, Great Valley Group, Sacramento Basin, California : Implication for Petroleum Exploration and Sequence Stratigraphy of Deep-Marine Strata. Bull. Amer. Assoc. Petrol. Geol, 82, 1575-1595.

吉岡克平, 1999 : デー夕解釈と地球統計学の役割. 物理 探査ハンドブック第 2 巻反射法地震探査, 物理探查学 会, 100-103. 